\title{
外断熱工法などを想定した“厚い壁”が日射熱取得量および 年間熱負荷に与える影響に関する検討

\author{
INFLUENCE OF “A THICK WALL” ASSUMING THE EXTERNAL INSULATION METHOD \\ ON SOLAR HEAT GAIN QUANTITY AND ANNUAL HEAT LOAD
}

\author{
谷口 景一朗*1 \\ Keiichiro TANIGUCHI
}

\begin{abstract}
The number of renovations using the external insulation method which has many advantages in terms of an energy saving performance will increase. However, "a thick wall" by the external insulation method may cause a solar radiation shading effect, so a pre-prediction by a simulation is essential for adoption especially in cold areas. In this study, a systematic heat load simulation is performed while changing the several factors of exteriors, and the influence of the solar heat gain quantity and the annual heat load due to a difference of the location of window frame in "a thick wall" are clarified.
\end{abstract}

Keywords: Apartment Houses, External Insulation Method, Wall Thickness, Heat Load Simulation, Solar Heat Gain Quantity, Annual Heat Load 集合住宅, 外断熱工法, 壁厚, 熱負荷シミュレーション, 日射熱取得量, 年間熱負荷

\section{1. 研究の背景と目的}

我が国は 2020 年以降の温室効果ガス削減に向けた中期目標とし て、2030 年度の温室効果ガス排出量を 2013 年度比 $26 \%$ 削減する ことを目標とする約束草案 1)を 2015 年に国連気候変動枠組条約 (UNFCCC) 事務局へ提出した。この目標を達成するため、住宅部 門においては新築住宅のみならず、既存住宅の断熱性能・省エネル ギー性能の向上を図ることの重要性が指摘されている。日本の住宅 ストックは 2013 年時点で約 5,210 万戸あり、そのうち集合住宅は 約 2,209 万戸と 4 割超を占める。特に 1960 年代ごろに始まった中 高層集合住宅の大量建設の際に鉄筋コンクリート $(\mathrm{RC})$ 造が広く採 用され、住宅ストックの 3 割超である約 1,630 万戸は鉄筋コンクリ 一ト造の集合住宅で占められている ${ }^{2}$ 。これらの集合住宅では、そ の価值の維持・向上を図るために大規模修絟の際に断熱改修が計画 されることも多いが、その有効な工法の一つが外断熱工法である。

外断熱工法はコンクリート躯体の外側から断熱材を施工するため、 内断熱工法に比べて熱橋を最小限に抑えられ、建物の省エネルギー 性能の向上に寄与する。また、コンクリート躯体が断熱材で保護さ れることで耐久性が向上する点や、居住空間を狭めず居ながら工事 が可能という点からも優れた特徴をもった工法である ${ }^{3)}$ 。既存集合 住宅の外断熱改修による熱負荷削減や温熱環境向上に関する既往研 究は多く、平川ら ${ }^{4}$ ) 外断熱改修前後の実測調查により、特に熱橋 となる壁際の床付近の室温および壁表面温度に外断熱改修による大 きな改善効果があることを示している。長谷川ら5もも外断熱改修し
た集合住宅の一部住戸の室内温度環境実測を行い、断熱性向上や躯 体の蓄熱効果を明らかにしている。平井ら ${ }^{6)}$ は鉄筋コンクリート造 1 階建ての実大実験モデルを用いて、外断熱改修の有無による躯体 内外表面温度差の違いを実測し、特に屋上スラブ部において外断熱 改修による表面温度差の抑制効果が大きいことを明らかにするとと もに、外断熱改修によりエアコン稼働時の消費電力量を最大 $1 / 2$ 程 度まで低減する効果を検証している。また、山本・芹川ら 788) は既存 集合住宅の建物全体での外断熱改修事例における改修前後のエネル ギー消費や温熱環境の改善効果の実態について、アンケートや実測 調査による把握を行っている。シミュレーションを用いた外断熱改 修の効果の検証については、加用ら 9)が実在する団地を対象に外断 熱化および開口部の複層ガラス化による熱負荷削減効果をシミュレ ーションにより示すとともに、居住者アンケートから改修コストに 対する懸念や政策による補助等の重要性を指摘している。また、広 瀬ら 10) は、既存集合住宅の断熱改修による省エネルギー効果や光熱 費の削減効果を、改修時のコストと光熱費削減効果による回収年数 および断熱材投入による $\mathrm{CO} 2$ 排出量とその回収年数の観点から評 価している。さらには、平川ら ${ }^{111}$ は、実在の既存集合住宅を対象に 室内温度と暖房エネルギー消費量の双方について外断熱改修の効果 を評価するとともに、外断熱改修後の集合住宅の室内温度推定式を 提案している。

一方で、近年では北海道、東北、北陸地方あるいは全国の山間部 といった、省エネルギー基準の 1 4 地域に属する冬期の寒さが厳し

\footnotetext{
*1 東京大学大学院工学系研究科建築学専攻 特任助教 · 修士 (工学)
}

Project Assist. Prof., Graduate School of Eng., The Univ. of Tokyo, M.Eng. 
い地域で、150 200 $\mathrm{mm}$ 程度の厚い断熱材による外断熱工法を採用 した改修の事例も報告されている ${ }^{12)}$ 。外断熱工法を採用する場合で も、開口部枠は原則既存躯体と緊結させて支持させる必要があるた め、改修後の外壁面より開口部枠の取付位置の方が室内側に位置す ることが多く、Fig.1 に示すように付加された断熱材による日射遮 蔽の影響を受けていることが予想される。壁厚による日射遮蔽効果 自体は日よけ効果係数算出ツール 13)等を用いて簡易的に評価する ことは可能だが、厚い断熱材を用いた外断熱工法によって日射熱取 得量の減少が暖房負荷の増大を招く懸念だけでなく、先般報告され ている断熱強化型住宅における中間期・夏期のオーバーヒート 14)の 抑制といった影響も考慮する必要があり、これらの評価は外皮の断 熱性能や内部発熱等の条件を与えた上で系統的に熱負荷シミュレー ションを行わなければ明らかにならない。しかし、熱負荷シミュレ ーションでは庇やルーバーといった日射遮蔽部材を除いて開口部廻 りの詳細は再現されないことが多く、既往論文でも付加された厚い 断熱材による日射遮蔽の影響は考慮されていない。

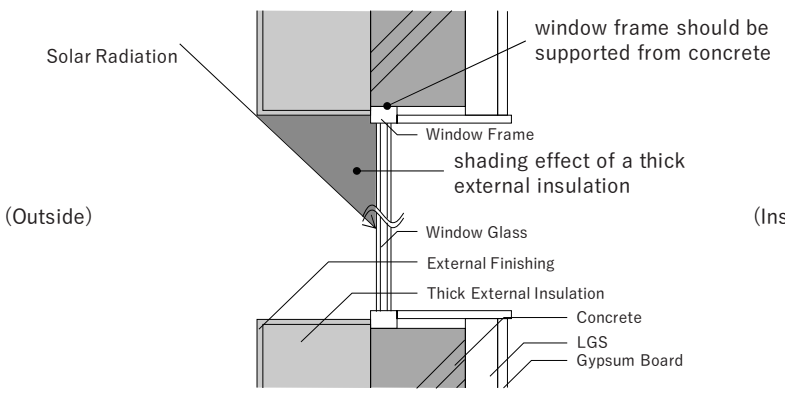

Fig.1 Diagram of External Insulation Method

以上の観点から、本研究では集合住宅を対象として、地域 / 主開 口方位 / 開口部サイズ / 開口部の形状 / ガラスの種別 / 断熱材 の厚さを変更しながら系統的な熱負荷シミュレーションを行い地域 ごとの年間熱負荷・熱収支の特性とそれに影響を与える因子を明ら かにするとともに、外断熱工法を想定した “厚い壁”における開口 部枠の取付位置の違いによる日射熱取得量および年間熱負荷への影 響を把握し、今後増加が見込まれる外断熱改修による熱負荷削減効 果を評価するための基礎データを整備することを目的とする。

\section{2. 熱負荷シミュレーションの概要}

\section{2-1. 解析対象住戸の概要}

解析対象住戸として、Fig.2 で示すような階段室型の RC 造集合 住宅の 1 住戸（幅 $5.64 \mathrm{~m} \times$ 奥行 $7.56 \mathrm{~m} \times$ 天井高 $2.4 \mathrm{~m}$ ）を想定し た。住戸全体を解析対象領域とし、リビング・寝室の一方の壁面 (図 中下側）に設けた開口部の方位 / サイズ / 形状 / ガラスの種別 / 枠の取付位置を変更して熱負荷シミュレーションを行った。なお、 空調室はリビング・寝室のみとした。また、対象住戸は 4 階建て集 合住宅の 3 階に位置し、床面高さは地上 $5.7 \mathrm{~m}$ とした。

\section{2-2. 熱負荷シミュレーションの設定}

熱負荷シミュレーションプログラムには、EnergyPlus (Ver.9.0.1) を用いた。気象データは、epw (EnergyPlus Weather Data）形式に変換した札幌・東京・鹿児島の標準年拡張アメダス気
象データ（2010 年版）を使用した。Fig.3にリビング・寝室の在室 スケジュールおよびリビング・寝室 / サニタリー / 浴室の照明・発 熱機器の負荷スケジュールを示す。いずれのスケジュールも解析対

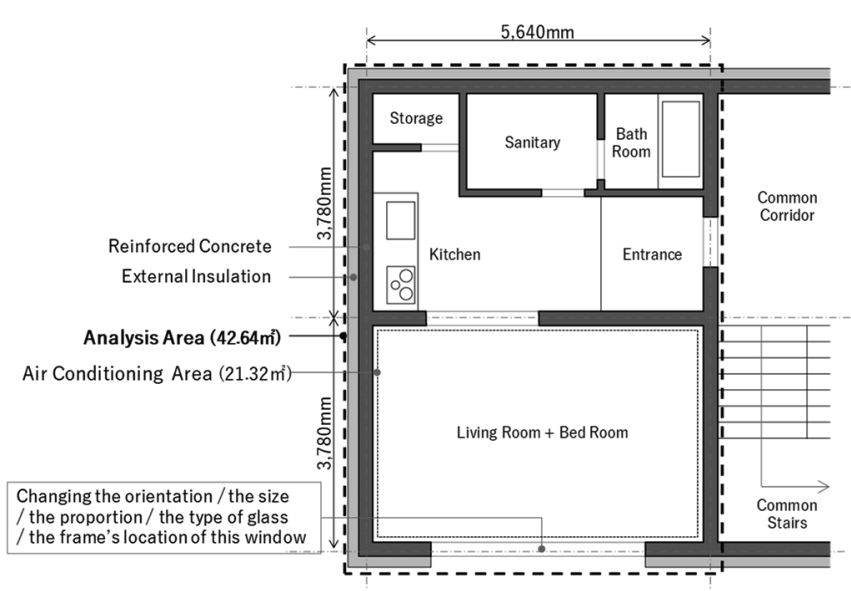

Fig.2 Plan of Analysis Dwelling Unit
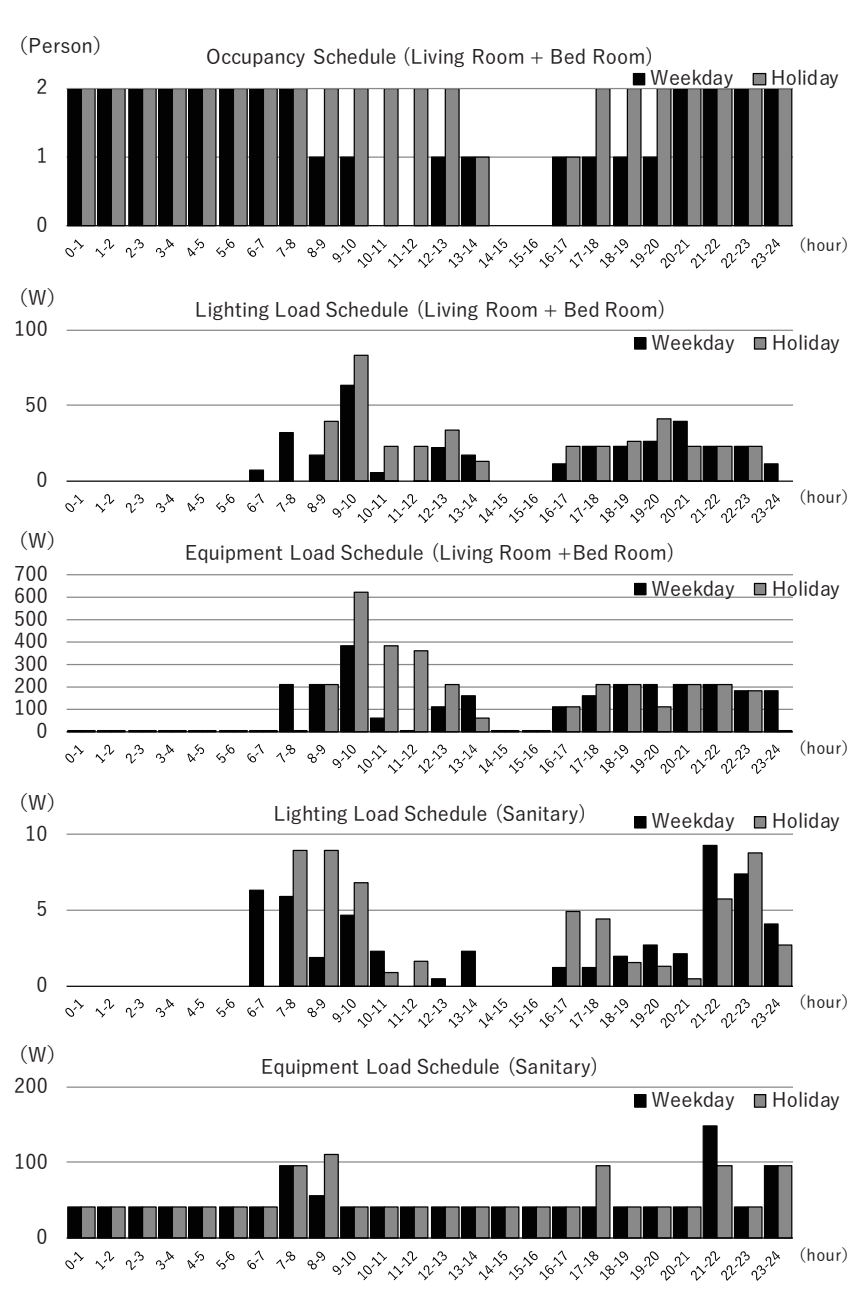

(W) Lighting Load Schedule (Bath Room)

-Weekday $\square$ Holiday

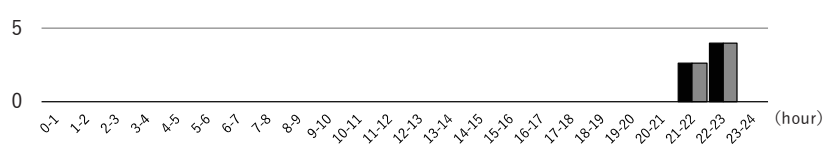

Fig.3 Occupancy and Load Schedule 
象住戸を 2 人世帯と想定し、自立循環型住宅開発プログラム 15)を参 考に設定した 注1)。なお、リビング・寝室に在室者がいる時間帯は就 寝時を含めて空調時間帯と想定し、冷房設定温度 $27^{\circ} \mathrm{C} /$ 暖房設定 温度 $20^{\circ} \mathrm{C}$ とした。また、人体からの発熱量は $100 \mathrm{~W} /$ 人とした。Fig.4 に解析モデルを示す。隣接住戸および共用廊下・階段室に接する壁 面と天井面、床面について本来は居住の有無や生活スケジュールの 違いによって室温変動が異なるため熱の移動は生じるが、本研究で は外壁の断熱材厚さが開口部の日射熱取得量および年間熱負荷に与 える影響の検討に特化するため、隣接住戸も同じ生活スケジュール で居住するものと仮定し、熱の移動は発生しない断熱境界として設 定した。開口部については Fig. 5 に示寸通り、四方に見付幅 $50 \mathrm{~mm}$

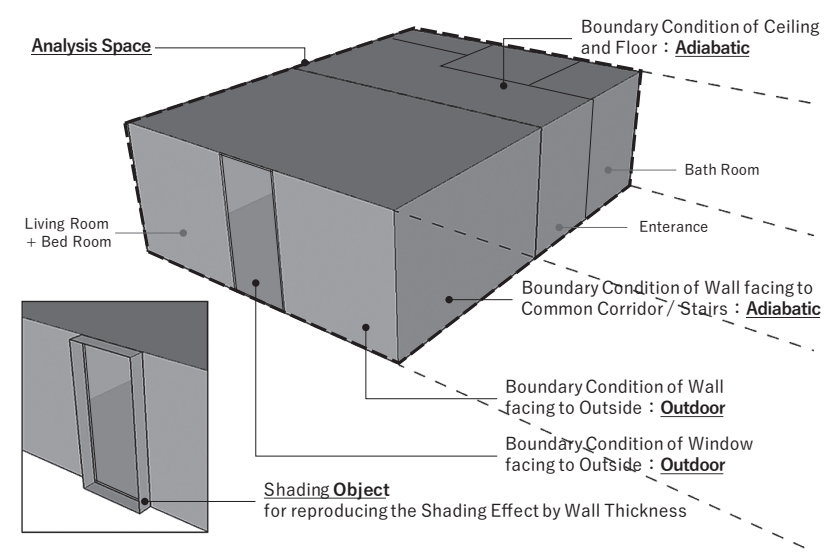

Fig.4 Analysis Models for Heat Load Simulation

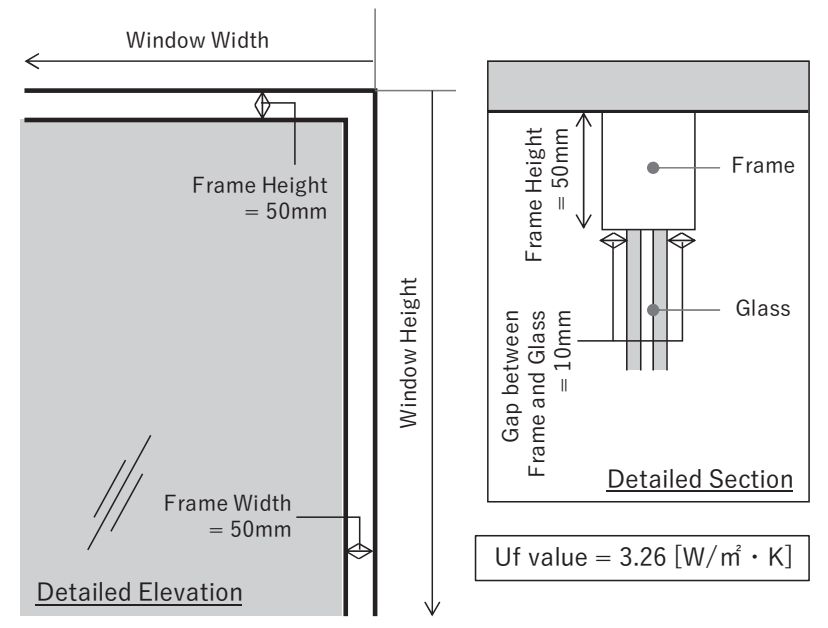

Fig.5 Details of Window Frame

Table 1 Constructions and Opaque Material Data Constructions

\begin{tabular}{|c|c|c|c|c|c|}
\hline \multirow[b]{2}{*}{ External Wall } & \multirow{2}{*}{$\begin{array}{c}\text { Outside } \\
\text { Plasterer } \\
5 \mathrm{~mm}\end{array}$} & $\leftarrow \ldots$ & 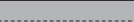 & 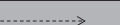 & \multirow{2}{*}{ 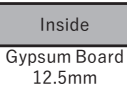 } \\
\hline & & \begin{tabular}{c|} 
EPS \\
$50 \mathrm{~mm}$ or $200 \mathrm{~mm}$
\end{tabular} & $\begin{array}{l}\text { Concrete } \\
180 \mathrm{~mm}\end{array}$ & Air Layer & \\
\hline Internal Wall & $\begin{array}{c}\text { Gypsum Board } \\
12.5 \mathrm{~mm}\end{array}$ & Air Layer & $\begin{array}{l}\text { Concrete } \\
180 \mathrm{~mm}\end{array}$ & Air Layer & $\begin{array}{c}\text { Gypsum Board } \\
12.5 \mathrm{~mm}\end{array}$ \\
\hline Internal Floor & $\begin{array}{c}\text { Concrete } \\
150 \mathrm{~mm}\end{array}$ & Air Layer & $\begin{array}{l}\text { Particle Board } \\
20 \mathrm{~mm}\end{array}$ & $\begin{array}{c}\text { Oak Flooring } \\
12 \mathrm{~mm}\end{array}$ & \\
\hline Internal Ceiling & $\begin{array}{l}\text { Concrete } \\
150 \mathrm{~mm}\end{array}$ & Air Layer & $\begin{array}{c}\text { Gypsum Board } \\
12.5 \mathrm{~mm}\end{array}$ & & \\
\hline
\end{tabular}

Opaque MaterialData

\begin{tabular}{c|r|r|r|r|r|r}
\hline & \multicolumn{1}{|c}{ Opaque Material Data } \\
\hline $\begin{array}{c}\text { Conductivity } \\
{[\mathrm{W} / \mathrm{m} \cdot \mathrm{K}]}\end{array}$ & 1.40 & 1.50 & 0.03 & 0.16 & 0.19 & 0.15 \\
\hline $\begin{array}{c}\text { Density } \\
{[\mathrm{kg} / \mathrm{m} 3]}\end{array}$ & 2100 & 2200 & 25 & 785 & 680 & 720 \\
\hline $\begin{array}{c}\text { Specific Heat } \\
{[\mathrm{J} / \mathrm{kg} \cdot \mathrm{K}]}\end{array}$ & 880 & 800 & 1000 & 830 & 1590 & 1300 \\
\hline
\end{tabular}

ずつの枠（アルミ樹脂複合サッシを想定、Uf 值 $=3.26 \mathrm{~W} / \mathrm{m}^{2} ・ \mathrm{~K} ）$ を 再現し、2-3 章 7)で記述する開口部枠の取付位置について「Middle」 あるいは「Back Side」の場合は、開口部四方に日射遮蔽部材を設け、 壁厚による日射遮蔽の影響を再現した。なお、周辺建物等による日 射遮蔽の影響はないものとして解析を行っている。換気回数は 0.5 回/hとし、熱交換は行わない設定とした。Table 1 に各仕上の構成 とその物性值を示す。

\section{2-3. 検討ケース}

上記の解析対象空間に対して、制御因子として地域 / 主開口方 位 / 開ロサイズ (開口率) / 開口部の形状 / ガラスの仕様 / 断 熱材の厚さ / 開口部枠の取付位置の 7 因子を変更しながら熱負荷 シミュレーションを行った。本研究において検討した各因子とその 検討水準を Table 2 に示寸。なお、表中各因子（地域を除く）のう ち下線を付した水準が基準ケース（Base）の条件を示す。

Table 2 Factors and Levels for Heat Load Simulation

Underline : Base Case's Condition

\begin{tabular}{|c|c|c|c|c|}
\hline Factor & \multicolumn{4}{|c|}{ Level } \\
\hline Site & $\begin{array}{l}\text { Sapporo } \\
\text { (Zone 2) }\end{array}$ & $\begin{array}{l}\text { Tokyo } \\
\text { (Zone 6) }\end{array}$ & $\begin{array}{l}\text { Kagoshima } \\
\text { (Zone 7) }\end{array}$ & \\
\hline $\begin{array}{l}\text { Window } \\
\text { Orientation }\end{array}$ & $\underline{\text { South }}$ & East & West & North \\
\hline $\begin{array}{c}\text { Window Size } \\
\text { (Window-to-Wall Ratio) }\end{array}$ & $10 \%$ & $\underline{20 \%}$ & $50 \%$ & $75 \%$ \\
\hline $\begin{array}{l}\text { Window } \\
\text { Proportion }\end{array}$ & Vertical & Square & Horizontal & \\
\hline Window Glass* & $\underset{\text { (FL6mm) }}{\text { Single Clear }}$ & $\begin{array}{l}\text { Double Low-e } \\
\text { Heat Reflecting Type } \\
\text { (LE6+Airr+FL L } 6 \mathrm{~mm}) \\
\end{array}$ & 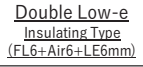 & $\begin{array}{l}\text { Single Solar } \\
\text { Reflective } \\
\text { (SRGGmm) }\end{array}$ \\
\hline $\begin{array}{l}\text { Thickness of } \\
\text { Insulation }\end{array}$ & $\underline{50 \mathrm{~mm}}$ & $\begin{array}{c}200 \mathrm{~mm} \\
\text { (Only Sapporo) }\end{array}$ & & \\
\hline $\begin{array}{c}\text { Location of } \\
\text { Window Frame }\end{array}$ & Front Side & Middle & Back Side & \\
\hline
\end{tabular}

\section{1）地域 $/$ Site}

地域は、年間熱負荷において冬期の暖房負荷が主である札幌（省 エネ基準地域区分 : 2 地域）と夏期の冷房負荷が主である鹿児島 (7 地域)、および冷房負荷と暖房負荷の双方の検討が必要な東京 (6 地 域）の 3 地点について検討を行った。

\section{2) 主開口方位 $/ W i n d o w ~ O r i e n t a t i o n$}

解析対象空間であるリビング・寝室に設けた開口部について、面 する方位の違いによる影響を把握するため、南 (South)、東 (East)、 西 (West)、北（North）それぞれに正対した場合の計 4 ケースに ついて解析を行った。

3）開ロ部サイズ (開口率) /Window Size (Window-to-Wall Ratio) 空面積の大きさの違いによる影響を把握するため、開口部サイズ (開口率) は 10\%、20\%、50\%、75\%の計4ケースについて解析を 行った。なお、本研究における開口率とは、開口部を設けた壁面積 （開口部面積を含む）に対する開口部面積の割合と定義する。いずれ の開口部サイズについても、開口部中心は壁中心と一致させた。

\section{4）開口部の形状 /Window Proportion}

開口部の形状の違いによる影響を把握するため、開口部の形状は 縦長 (Vertical)、正方形 (Square)、横長 (Horizontal) の計 3 个 ースについて解析を行った。3) 開口部サイズ（開口率）および 4) 
開口部の形状について、本研究において検討した全 10 ケースの立 面図および開口部面積を Table 3 に示す。

\section{5）ガラスの種別 /Window Glass}

ガラスの種別については、フロート単板ガラス（Single Clear、 FL6mm)、Low-e 複層ガラス日射遮蔽型（Double Low-e Heat Reflecting Type、LE6+Air6+FL6mm)、Low-e 複層ガラス日射取 得型（Double Low-e Insulating Type、FL6+Air6+LE6mm）およ び熱線反射単板ガラス（Single Solar Reflective、SRG6mm）の 4 ケースについて解析を行った。Table 4 に各ガラスの物性值を示す。

Table 3 Size and Proportion of Window

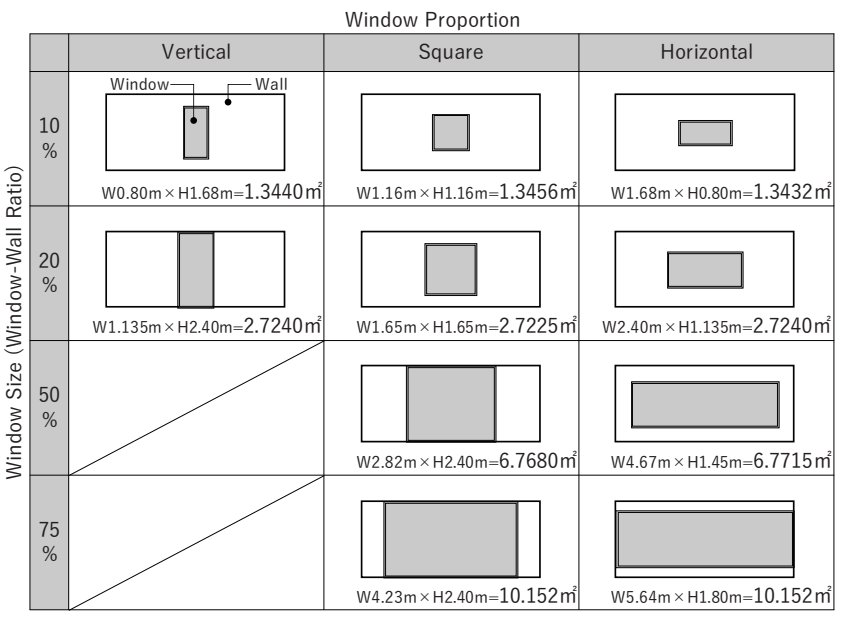

Table 4 Glass Material Data

\begin{tabular}{c|r|r|r|r}
\hline & \multicolumn{1}{|c|}{$\begin{array}{c}\text { Single Clear } \\
\text { (FL6mm) }\end{array}$} & $\begin{array}{c}\text { Double Low-E } \\
\text { Heat Reflecting Typ } \\
\text { (LE6+Air6+FL6mm) }\end{array}$ & $\begin{array}{c}\text { Double Low-E } \\
\text { Insulating Yype } \\
\text { (FL6+Air6+L66mm) }\end{array}$ & $\begin{array}{c}\text { Single Solar } \\
\text { Reflective } \\
\text { (SRG6mm) }\end{array}$ \\
\hline U-Factor [W/m2 $\cdot \mathrm{K}]$ & 5.90 & 2.50 & 2.48 & 5.30 \\
\hline $\begin{array}{c}\text { Solar Heat } \\
\text { Gain Coefficient }\end{array}$ & 0.85 & 0.28 & 0.59 & 0.40 \\
\hline Visible Transmittance & 0.894 & 0.496 & 0.770 & 0.309 \\
\hline
\end{tabular}

6) 断熱材厚さ/Thickness of Insulation

外断熱改修で付加する断熱材厚さについては $50 \mathrm{~mm}$ を基準とし、 寒冷地である札幌のみ厚さ $200 \mathrm{~mm}$ についても解析を行った。

\section{7) 開口部枠の取付位置/Location of Window Frame}

開口部枠の取付位置について、Fig.6 に示す通り外壁面合わせ (Front Side)、壁中央 (Middle) および内壁面合わせ (Back Side) の 3 ケースについて解析を行った。なお、従来の壁厚を考慮しない 熱負荷シミュレーションの結果については Front Side の解析結果 を代用して、開口部枠の取付位置を考慮することによる熱負荷シミ ユレーションへの影響の分析を行った。

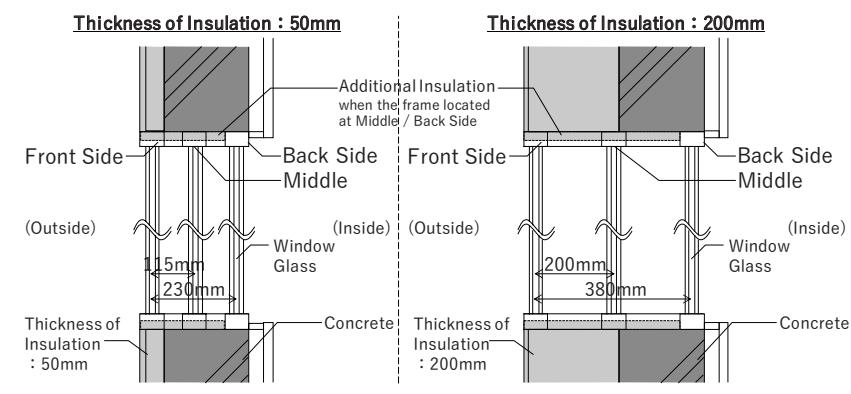

Fig.6 Location of Window Frame
3. 熱負荷シミュレーションの結果および考察

3-1. 壁厚を考慮しない解析の結果について

\section{1）地域 $/$ Site : 東京の場合}

基準ケースの月別熱負荷および年間熱収支の解析結果を Fig.7、 Fig. 8 に示す。基準ケースでは冷房負荷最大月は 8 月で約 $1,475 \mathrm{MJ}$ 、 暖房負荷最大月は 2 月で約 $340 \mathrm{MJ}$ となっており、年間冷房負荷は 約 4,540MJ、年間暖房負荷は約 900MJ であり、中間期である 4 5 月および 11 月は冷房負荷・暖房負荷がほぼ発生しない結果となっ た。年間熱収支の結果（Fig.7）より、ガラスの種別が Low-e 複層 ガラス日射取得型であるため、日射熱取得（Solar Heat Gain）が 大きいことが冷房負荷の増大および暖房負荷の削減に寄与している と考えられる。また、換気設備について本検討では熱交換を行わな い設定としているため、特に冬期における換気による熱損失 （Ventilation Heat Loss）が大きい。

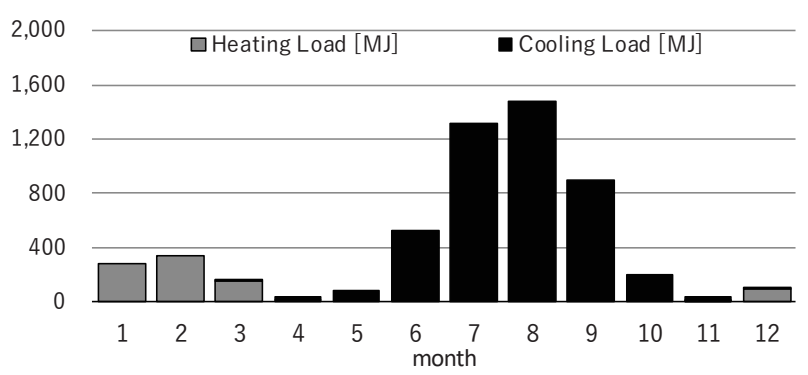

Fig.7 Heat Load of Each Month (Base Case, Site : Tokyo) $\square$ People Heat Gain $\square$ Electric Equipment Heat Gain aWindow Heat Gain / Loss (without solar heat gain) Wall Heat Gain / Loss

a Ventilation Heat Gain / Loss $\quad$ - Heating / Cooling Load

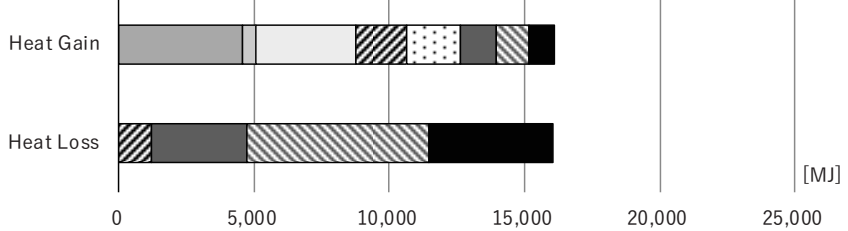

Fig.8 Heat Balance (Base Case, Site : Tokyo)

Fig.9 に地域／Site を東京とした場合の制御因子ごとの計算結果 を示す。基準ケース (Base) の年間熱負荷は約 5,440MJ となった。 主開口方位について、東・西・北向きの場合はいずれも冬期におけ る日射熱取得量が小さくなることから、基準ケース（Base）よりも 年間熱負荷は大きくなった。開口部サイズについて、開口率が 10\% と $20 \%$ のースでは年間熱負荷はほぼ同じとなるが、これは開口部 サイズを大きくすることによる日射熱取得量の増大が冷房負荷増大 および暖房負荷削減に与える影響が同程度であるためと考えられる。 一方で、開口率を 50\%および $75 \%$ としたケースでは、日射熱取得 量が大きくなることによる冷房負荷増大一の影響の方が大きくなる ため、年間熱負荷は増大した。なお、開口部の形状については壁厚 を考慮しない解析の場合は形状の違いによる年間熱負荷への影響は 見られなかった。ガラスの種別については、フロート単板ガラスの 場合、熱貫流率が大きく日射熱取得率も大きいことから冷房負荷が 増大し、年間熱負荷が最も大きくなった。Low-e 複層ガラス日射遮 蔽型および熱線反射単板ガラスの場合、いずれも日射熱取得率が Low-e 複層ガラス日射取得型よりも小さく夏期の日射熱取得が減少 
するため冷房負荷は基準ケース（Base）よりも小さくなる。一方で 冬期の日射熱取得量も減少するとともに、熱貫流率が Low-e 複層ガ ラス日射取得型よりも大きいことから開口部からの熱損失が大きい ため暖房負荷は基準ケース（Base）よりも大きくなり、年間熱負荷 については Low-e 複層ガラス日射遮蔽型は基準ケース（Base）と 同程度、熱線反射単板ガラスではやや大きくなった。

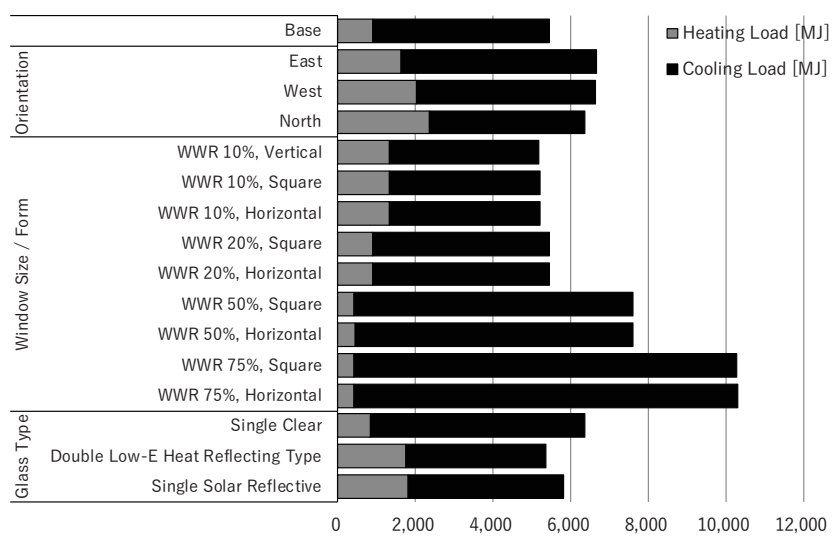

Fig.9 Annual Heat Load of Each Cases (Site : Tokyo)

\section{2）地域 $/$ Site：札幌の場合}

基準ケースの月別熱負荷および年間熱収支の解析結果を Fig. 10、 Fig. 11 に示す。基準ケースでは冷房負荷最大月は 8 月で約 $565 \mathrm{MJ}$ 、 暖房負荷最大月は 1 月で約 $1,390 \mathrm{MJ}$ となっており、年間冷房負荷 は約 $1,140 \mathrm{MJ}$ 、年間暖房負荷は約 $5,870 \mathrm{MJ}$ であり、冷房負荷が発 生するのは 7 9 月のほぼ 3 ケ月間のみである。年間熱収支の結果 （Fig.10）より、換気による熱損失（Ventilation Heat Loss）が大 きいことが暖房負荷の増大の原因となっており、札幌のように冬期 の寒さが厳しい地域では全熱交換器等の設置により、換気による熱 損失を抑える工夫が必要であることがわかる。また、壁面からの熱 損失（Wall Heat Loss）も大きく、断熱材厚さ $50 \mathrm{~mm}$ が適切であ るか検討を要することが示唆された。

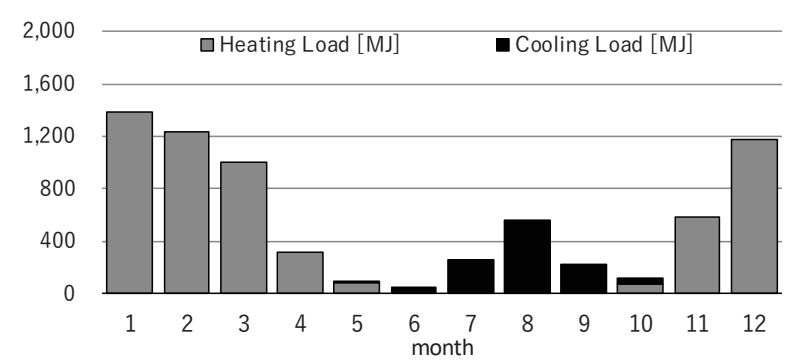

Fig.10 Heat Load of Each Month (Base Case, Site : Sapporo) $\square$ People Heat Gain

口Electric Equipment Heat Gain घWindow Heat Gain / Loss (without solar heat gain) 口Solar Heat Gain

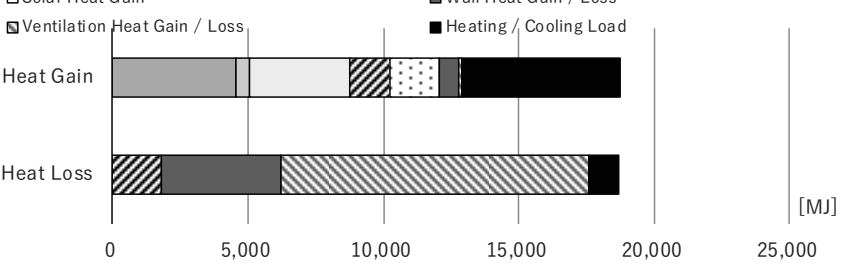

Fig.11 Heat Balance (Base Case, Site : Sapporo)
Fig.12 に地域／Site を札幌とした場合の制御因子ごとの計算結 果を示す。基準ケース（Base）の年間熱負荷は約 7,010MJ となっ た。主開口方位について、東京の場合と同様に東・西・北向きの場 合はいずれも冬期における日射熱取得量が小さくなることから、基 準ケース (Base) よりも年間熱負荷は大きくなった。開口部サイズ および形状についても東京の場合と同様の傾向が見られ、開口率が 10\%と $20 \%$ のースでは年間熱負荷はほぼ同じとなるが、開口率 を 50\%および $75 \%$ としたケースでは年間熱負荷は増大した。開口 部の形状についても形状の違いによる年間熱負荷への影響は見られ なかった。ガラスの種別については、日射熱取得率の小さい Low-e 複層ガラス日射遮蔽型および熱線反射単板ガラスではいずれも冬期 の暖房負荷増大の影響が大きく、年間熱負荷も基準ケース（Base） より大きくなった。また、フロート単板ガラスでは日射熱取得量の 増大による夏期の冷房負荷増大が見られるとともに、ガラスの熱貫 流率が大きいため、冬期においても開口部からの熱損失が大きく暖 房負荷削減効果は見られなかった。結果として、基準ケース（Base） が最も年間熱負荷が小さい検討ケースとなり、札幌においては日射 熱取得量増大による冬期の暖房負荷削減に主眼を置いて検討すべき だが、いたずらに開ロサイズを大きくすると冷房負荷増大を招き、 結果的に年間熱負荷が増大するため注意を要することがわかった。

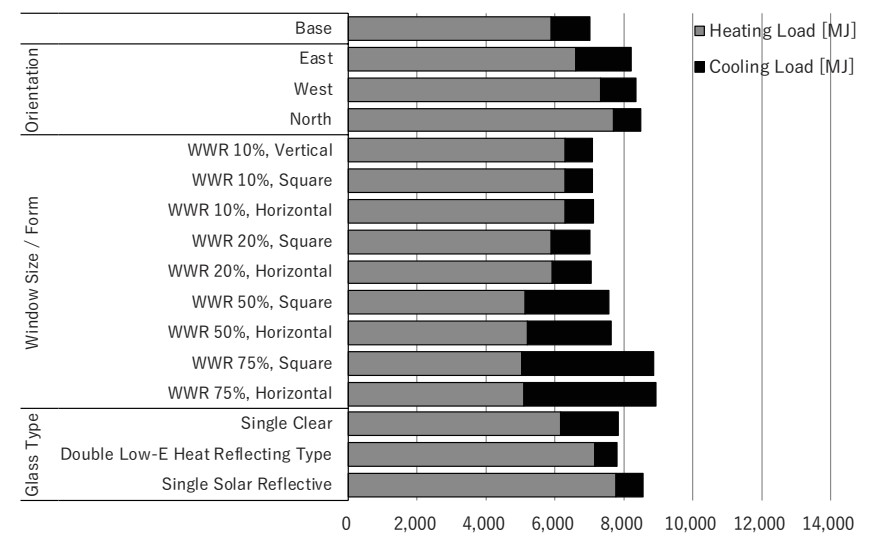

Fig.12 Annual Heat Load of Each Cases (Site : Sapporo)

\section{3）地域 /Site：鹿児島の場合}

基準ケースの月別熱負荷および年間熱収支の解析結果を Fig. 13、 Fig.14 に示す。基準ケースでは冷房負荷最大月は8月で約 1,690MJ、 暖房負荷最大月は 1 月で約 $190 \mathrm{MJ}$ となっており、年間冷房負荷は 約 6,570MJ、年間暖房負荷は約 $450 \mathrm{MJ}$ となった。年間熱収支 (Fig.13) より、壁面（Wall Heat Loss）および換気による熱損失 (Ventilation Heat Loss) が東京および札幌の場合と比べて小さく、 比較的温暖な気候により熱損失を小さく抑えられるため、冬期の暖 房負荷が抑制されていることがわかる。

Fig.15 に地域／Site を鹿児島とした場合の制御因子ごとの計算 結果を示す。基準ケース（Base）の年間熱負荷は約 7,020MJ とな った。主開口方位について、東・西向きの方が基準ケース（Base） よりも年間熱負荷は大きくなった。一方で北向きについては、日射 熱取得量の減少が暖房負荷増大および冷房負荷削減に与える影響が 同程度であるため、年間熱負荷は基準ケース（Base）と同程度とな 


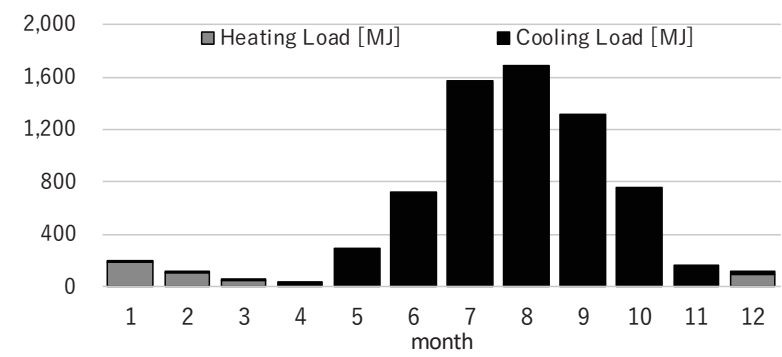

Fig. 13 Heat Load of Each Month (Base Case, Site : Kagoshima)

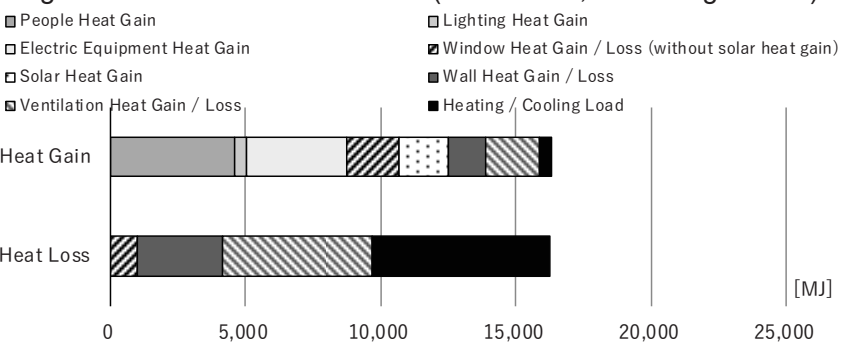

Fig.14 Heat Balance (Base Case, Site : Kagoshima)

った。開口部サイズについて、開口率が大きくなるにつれて日射熱 取得量が増えるため、特に夏期の泠房負荷が増大し、年間熱負荷も 増大した。開口部の形状については東京・札幌と同じ傾向が見られ た。ガラスの種別について、日射熱取得率の最も小さい Low-e 複層 ガラス日射遮蔽型が基準ケース（Base）よりも年間熱負荷が小さく なり、熱線反射単板ガラスの場合も日射熱取得量の減少による夏期 の泠房負荷削減の効果が見られ、基準ケース（Base）と同程度の年 間熱負荷となった。以上より、鹿児島においては主開口方位も考慮 しつつ日射熱取得量削減による夏期の泠房負荷削減に主眼を置いて 検討すべきことが示唆された。

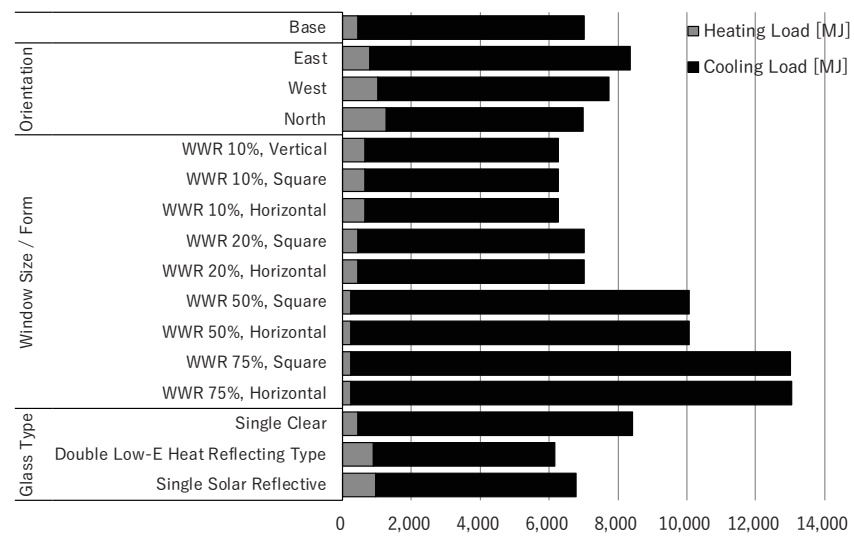

Fig.15 Annual Heat Load of Each Cases (Site : Kagoshima)

\section{3-2. 壁厚を考慮した解析の結果について}

次に、外断熱工法を想定した “厚い壁” における開口部枠の取付 位置の違いによる日射熱取得量および年間熱負荷への影響を把握す るため、壁厚による日射遮蔽効果を開口部四方に設けた日射遮蔽部 材で再現した熱負荷シミュレーションの結果を考察する。Table 5 に地域を東京、主開口方位を南向きおよび東向き、開口率を $20 \%$ 、 ガラスの種別を Low-e 複層ガラス日射取得型としたケースの開口 部の形状（Window Proportion）ごとの開口部枠の取付位置と年間
熱負荷 / 日射熱取得量との関係を示す。年間熱負荷・日射熱取得量 はいずれも総量を示す棒グラフを表中左側、開口部枠の取付位置が 外壁面合わせ（Front Side：壁厚を考慮しない熱負荷シミュレーシ ヨンと同条件）のケースの值を 1.0 とした場合の壁中央（Middle） および内壁面合わせ（Back Side）の值の比率を示寸折れ線グラフ を表中右側に示している。主開口方位が南向きの場合、開口部の形 状に関わらず、開口部枠の取付位置が壁中央および内壁面合わせと 室内側に移動するにつれて、日射熱取得量は削減される傾向が見て とれる。特に開口部の形状が横長（Horizontal）のケースが最も削 減率が大きく、外壁面合わせと比べて壁中央では約 13\%減、内壁面 合わせでは約 $25 \%$ 減という結果となった。これは太陽高度が高い南 からの直射光に対して、開口部上部の壁厚が庇と同様の日射遮蔽の 役目を果たしており、特に開口部の形状が横長の場合、この開口部 上部の壁厚による日射遮蔽効果の影響が及ぶ面積が開口部面積に占 める割合が大きいためと考えられる。一方で、主開口方位が東向き の場合も同様に開口部枠の取付位置が壁中央および内壁面合わせと 室内側に移動するにつれて日射熱取得量は削減されるが、開口部の 形状による削減率の違いは大きくは見られない。これは、太陽高度 が低い南西および西からの直射光に対して、開口部上部および左右 の壁厚が庇と袖壁双方と同様の日射遮蔽の役目を果たしているため、 開口部面積に占める壁厚による日射遮蔽効果の影響が及ぶ面積割合 が、開口部の形状によらず同程度であるからと推察される。同様の 傾向は、他の開口率の場合にも見られるが、開口率が $75 \%$ の場合は、 開口部面積の増大に伴い、相対的に開口部面積に占める壁厚による 日射遮蔽の影響が及ぶ面積割合が小さくなるため、主開口方位が南 向きの場合でも、開口部の形状の違いによる明確な削減率の違いは 大きくは見られなかった。日射熱取得量の削減により、開口部の形 状がいずれのケースにおいても冷房負荷は、開口部枠の取付位置が 外壁面合わせの場合と比較して壁中央では約 5\%、内壁面合わせで は約 10\%削減する一方で、暖房負荷は外壁面合わせの場合と比較し て壁中央で約 $12 \%$ 、内壁面合わせで約 24\%増大寸る結果となった。 本ケースでは、年間熱負荷は開口部枠の取付位置が外壁面合わせの ケースと比べ、壁中央および内壁面合わせのケースでは削減される 結果となったが、これは本研究のシミュレーション条件では東京に おいて冷房負荷の方が暖房負荷よりも大きいため、壁厚による日射 遮蔽がもたらす冷房負荷削減効果が大きかったためと考えられる。

Table 6 に地域を札幌、主開口方位を南向き、開口率を $20 \%$ 、開 口部の形状を縦長、ガラスの種別を Low-e 複層ガラス日射取得型、 そして断熱材の厚さを $200 \mathrm{~mm}$ としたケースの開口部枠の取付位置 と年間熱負荷・日射熱取得量との関係を示す。断熱材が厚くなるこ とにより、断熱材厚さが $50 \mathrm{~mm}$ のケースと比較して壁厚による日 射遮蔽の影響はさらに大きくなり、日射熱取得量は開口部枠の取付 位置が外壁面合わせのケースと比較して、壁中央で約 $20 \%$ 、内壁面 合わせでは約 35\%削減された。これにより、暖房負荷は開口部枠の 取付位置が外壁面合わせのケースより、壁中央で約 7\%(約 280MJ) 増大、内壁面合わせで約 $12 \%$ （約 520MJ）増大し、年間熱負荷も 開口部枠の取付位置が室内側に移動するにつれて増大寸る結果とな った。札幌のように、寒冷地であり断熱改修時に暖房負荷削減を意 図して厚い断熱材の使用が想定される地域においては、壁厚による 日射遮蔽の影響を熱負荷シミュレーションで正しく再現しなければ、 
Table 5 Annual Heat Load and Annual Solar Heat Gain Quantity for Each Location of Window Frame (Site: Tokyo, Window Size: WWR 20\%, Glass Type: Double Low-e Insulating Type, Thickness of Insulation: 50mm)

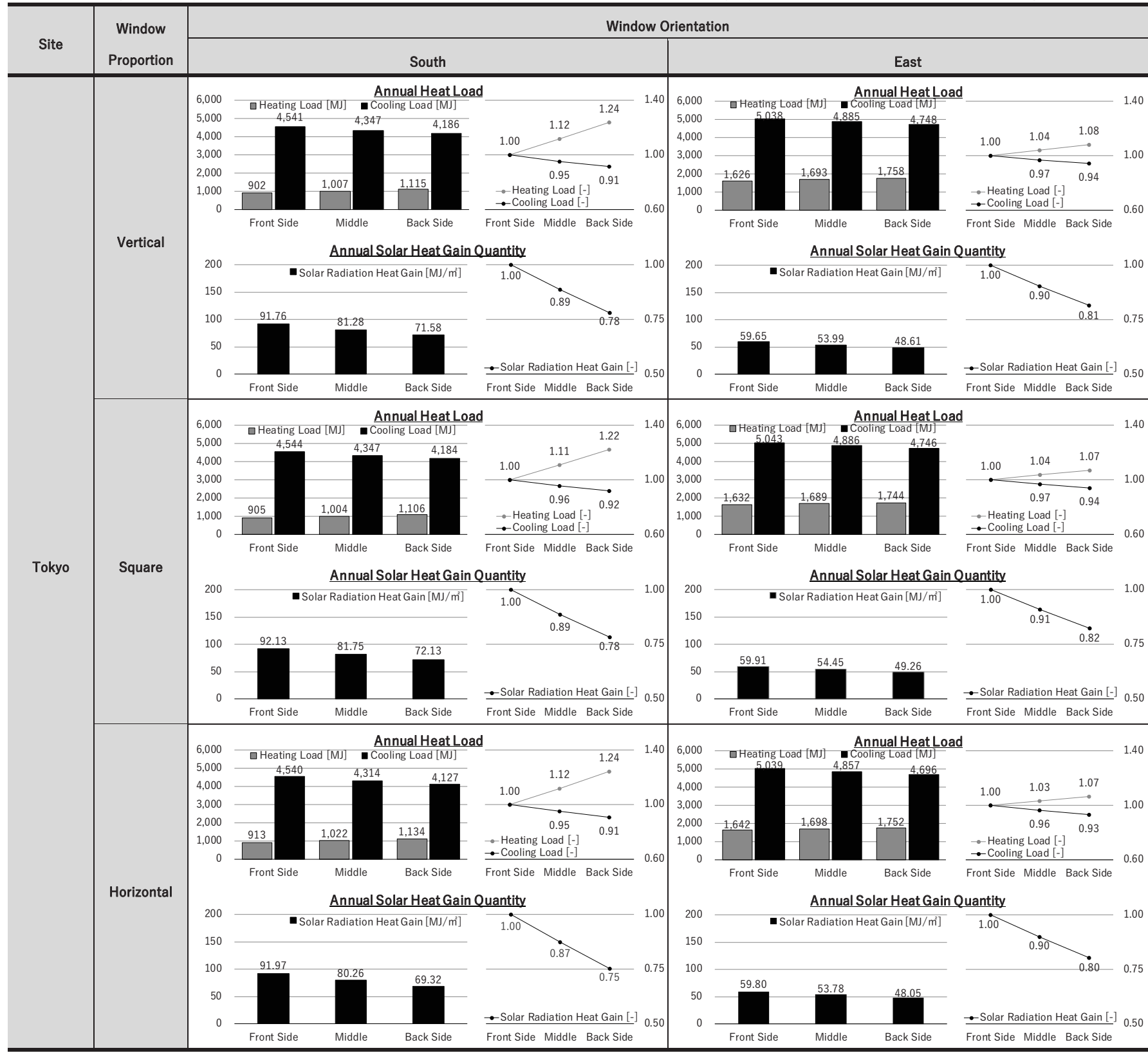

Table 6 Annual Heat Load and Annual Solar Heat Gain Quantity for Each Location of Window Frame (Site: Sapporo, Window Size: WWR 20\%, Glass Type: Double Low-e Insulating Type, Thickness of Insulation: 200mm)

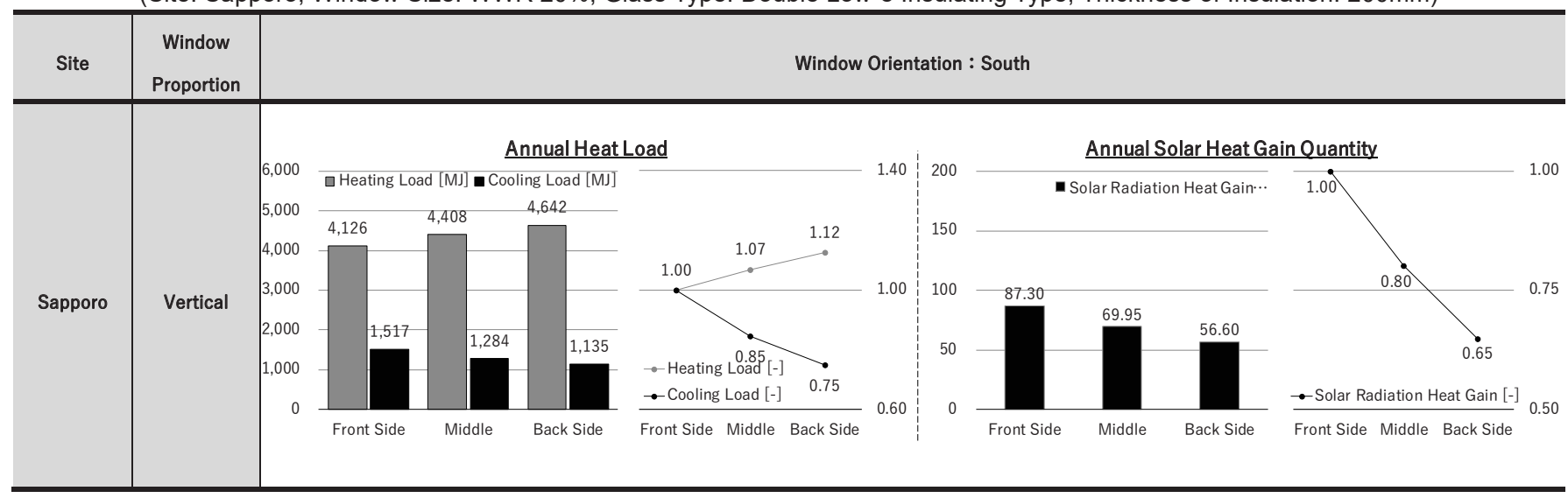


年間熱負荷を小さく算出してしまう危険性が把握できた。熱負荷シ ミュレーションを設計時の事前検討に生かすためには、正しく冷房 負荷と暖房負荷のバランスを把握することが不可欠であり、特に開 口部枠の取付位置が室内側となる場合には壁厚による日射遮蔽の影 響を熱負荷シミュレーションで正しく再現することが重要である。

\section{4. まとめ}

本研究では、今後事例の増加が想定される集合住宅の外断熱改修 に着目し、主開口方位 / 開口部サイズ / 開口部の形状 / ガラスの 種別 / 断熱材の厚さを変更しながら系統的な熱負荷シミュレーシ ヨンを行い地域ごとの年間熱負荷・熱収支の特性とそれに影響を与 える因子を明らかにするとともに、断熱材を付加した “厚い壁”に おける開口部枠の取付位置の違いによる日射熱取得量および年間熱 負荷への影響に関する基礎データの整備を行い、次の知見を得た。

1) 東京では、冷房負荷および暖房負荷双方の削減を検討する必 要があるが、使用するガラスの種別によって冷房負荷・暖房負 荷の大小の傾向が異なることに注意を要する。ガラスの種別 を Low-e 複層ガラス日射取得型とした場合、主開口方位は南 向きとした上で開口率を小さくした方が年間熱負荷を小さく することができる。

2) 札幌では、暖房負荷削減を主とした検討が求められるが、開口 率をいたずらに大きくすると夏期の日射熱取得量の増大によ り、泠房負荷が増大し年間熱負荷も増大寸るため、適切な開口 サイズの検討が必要である。

3) 鹿児島では、冷房負荷削減を主とした検討が求められ、開口率 を小さくした方が年間熱負荷を小さくすることができる。また、 ガラスの種別についても日射熱取得率の小さい Low-e 複層ガ ラス日射遮蔽型の方が、年間熱負荷が小さくなる。

4) “厚い壁”による日射遮蔽の影響を考慮して熱負荷シミュレー ションを行った場合、断熱材厚さが $50 \mathrm{~mm}$ でも開口部枠の取 付位置が外壁面合わせの場合と内壁面合わせの場合で約 $25 \%$ 日射熱取得量が削減され、冷房負荷 / 暖房負荷へも影響を与 えることがわかった。特に札幌のように冬の寒さが厳しく、厚 い断熱材（本研究では 200mm）を用いた外断熱工法の採用が 想定される地域では、壁厚による日射遮蔽の影響により暖房負 荷 / 年間熱負荷ともに増大寸る可能性がある。

以上より、壁厚による日射遮蔽の影響は厚さ $50 \mathrm{~mm}$ 程度の断熱 材を用いた外断熱工法においても日射熱取得量および年間熱負荷一 の影響が認められ、そのような工法を採用した建物の年間熱負荷削 減効果を設計時に正確に把握寸るためには、本研究で行ったように 開口部四方に壁厚分の奥行を有する日射遮蔽部材を模擬的に設け、 壁厚による日射遮蔽の影響を再現する必要があることが分かった。 特に、寒冷地では暖房負荷削減を意図して設置される厚い断熱材が 開口部枠の取付位置によっては、暖房負荷および年間熱負荷の増大 に寄与してしまう危険性があるため、本研究で提案する手法を用い た熱負荷シミュレーションを行いながら、断熱材厚さのみならず開 口部枠の取付位置についても十分な検討を行うことが望ましい。な お本研究では、開口部を 1 か所に限定し、開口部の各制御因子が日 射熱取得量および年間熱負荷に与える影響について検討を行ったが、 より現実的な平面計画である複数の開口部を設けた場合には、壁厚

による日射遮蔽の影響はさらに大きくなることが予想されるため、 今後検討が必要である。また、集合住宅での設置が予想されるべラ ンダ等の影響についても検討を進める必要があろう。加えて、年間 熱負荷と開口部の各因子との関係については、あくまで $2-2$ 章で述 ベたシミュレーション条件下での結果であり、内部発熱量や外皮の 断熱性能、日射遮蔽部材の有無等によって年間熱負荷の増減傾向は 影響を受けるため、今後更なる検証を加え、外断熱工法による熱負 荷削減効果を正しく予測する手法の整備を進めていく予定である。

注

注1）解析対象住戸はリビングと寝室（Living Room + Bed Room）、および 洗面脱衣室と便所（Sanitary）がそれぞれ一室にまとまった平面計画 となっている。各室の負荷設定について、「Living Room + Bed Room」 は自立循環型住宅開発プログラム ${ }^{15)}$ に示す「居間台所」と「寝室」、 「Sanitary」については「洗面脱衣」と「1F便所」の負荷設定を参考に 面積按分して求めた。また、照明負荷については LED 照明器具の使用 を想定し、各室の消費電力を以下の表のとおりに設定した。

\begin{tabular}{|c|c|c|}
\hline Living Room + Bed Room & Sanitary & Bath Room \\
\hline $83.0[\mathrm{~W}]$ & $12.0[\mathrm{~W}]$ & $4.0[\mathrm{~W}]$ \\
\hline
\end{tabular}

\section{参考文献}

1) Ministry of Economy, Trade and Industry: Submission of Japan's Intended Nationally Determined Contribution, 2015 経済産業省：日本の約束草案（2030 年度温室効果ガス排出削減目標）, 2015

2) Ministry of Internal Affairs and Communications: Housing and Land Survey, 2013 総務省：平成 25 年住宅・土地統計調査, 2013

3) Institute for Building Environment and Energy Conservation: Design Guidelines for Low Energy Housing with Validated Effectiveness -Renovation Edition-, 2018

一般社団法人建築環境・省エネルギー機構：改修版自立循環型住宅一 の設計ガイドライン エネルギー消費 50\%削減を目指す住宅設計, 2018

4) H. Hirakawa, T. Hasegawa: Study of Thermal Improvement of Concrete Apartment by External Insulation Renewal, Proceeding of the Architectural Research Meetings, Hokkaido Chapter, Architectural Institute of Japan, No.77, pp.201-204, 2004.7 平川秀樹，長谷川寿夫： $\mathrm{RC}$ 造集合住宅の外断熱改修による室内温熱環 境改善効果, 日本建築学会北海道支部研究報告集, No. 77, pp. 201-204, 2004. 7

5) T. Hasegawa, A. Fukushima, J. Sato, S. Takei: A Case Study on the Large-scale Repairs with External Insulation on a High-rise Condominium Part 2 Effects of Room Temperature and Energy Conservation depend on Repairs with External Insulation, Proceeding of the Architectural Research Meetings, Hokkaido Chapter, Architectural Institute of Japan, No.79, pp. 207-210, 2006. 7

長谷川寿夫，福島明，佐藤潤平，武井さやか：中高層民間分譲マンシ ヨンの外断熱改修事例研究 第 2 報 外断熱改修による室温環境と省エ ネルギー効果, 日本建築学会北海道支部研究報告集, No. 79, pp. 207210, 2006. 7

6) K. Hirai, M. Morimoto, S. Yi, H. Tsutsumi, Y. Komatsu: Improvement Performance Method for Existing RC Buildings by Experimentation with Full-scale Model -Effectiveness by External Insulation Finishing System-, Summaries of Technical Papers of Annual Meeting, Architectural Institute of Japan, FI , pp. 141-142, 2013. 7

平井健嗣, 森元みどり，李祥準，堤洋樹，小松幸夫：既存 RC 建築物 の性能向上改修に関する実験的研究 一実大モデルを用いた外断熱改修 の効果-, 日本建築学会大会学術講演梗概集, F- I , pp. 141-142, 2013. 7

7) M. Yamamoto, M. Serikawa, M. Sato: Validation of Effects of 
Retrofitting Existing Condominiums with External Insulation Part1 A Questionnaire Survey about the Influence of the Renovation on Energy Consumption, Summaries of Technical Papers of Annual Meeting, Architectural Institute of Japan, D- I , pp. 1267-1268, 2016. 7

山本正顕, 芹川真緒, 佐藤誠：既存集合住宅における外断熱改修の温 熱環境改善および省エネルギー効果の検証 その 1 居住者に対するア ンケートによるエネルギー使用に関する改修の影響の把握, 日本建築 学会大会学術講演梗概集, D- I , pp. 1267-1268, 2016.7

8) M. Serikawa, M. Yamamoto, M. Sato: Validation of Effects of Retrofitting Existing Condominiums with External Insulation Part2 An Analysis of the Influence of the Renovation on Energy Consumption, Summaries of Technical Papers of Annual Meeting, Architectural Institute of Japan, D- I , pp. 1269-1270, 2016.7 芹川真緒, 山本正顕, 佐藤誠：既存集合住宅における外断熱改修の温 熱環境改善および省エネルギー効果の検証 その 2 エネルギー消費に 関寸る考察, 日本建築学会大会学術講演梗概集, D- I , pp. 1269-1270, 2016. 7

9) G. Kayoh, N. Suzuki, S. Tanabe: Study on Renovation Planning of Multi-Family Dwellings for Heat-Load Reduction and 0ccupancy Satisfaction, Summaries of Technical Papers of Annual Meeting, Architectural Institute of Japan, D- II, pp. 27-28, 2002. 7 加用現空，鈴木信恵，田辺新一：集合住宅における熱負荷低減と居住 性向上を目的とした改修計画の検討, 日本建築学会大会学術講演梗概 集，D-II，pp. 27-28，2002.7

10) T. Hirose, H. Takaguchi: Investigation of Insulation Efficiency of Existing Apartments and Energy Saving of Insulation Renovation, Journal of Environmental Engineering (Transactions of AIJ), Vol.76, No. 664, pp. 581-586, 2011.6

広瀬拓哉, 高口洋人：既存集合住宅の断熱性能実態及びその改修によ る省エネルギー効果に関する研究, 日本建築学会環境系論文集, 第 76 巻, 第 664 号, pp. 581-586, 2011.6

11) H. Hirakawa, A. Fukushima, J. Sato, S. Ohashi, H. Hayama: Study on Prediction Method of External Thermal Insulation Retrofit Effects of Condominiums in Cold Region, Journal of Environmental Engineering (Transactions of AIJ), Vol.80, No.715, pp.711-721, 2015. 9

平川秀樹, 福島明, 佐藤潤平, 大橋周二, 羽山広文：寒冷地の既存マ ンションにおける外断熱改修効果の推定方法に関する研究, 日本建築 学会環境系論文集, 第 80 巻, 第 715 号, pp. 711-721, 2015.9

12) A+U Publishing Co., Ltd. : Architecture and Urbanism April 2018 Special Issue PASSIVETOWN, 2018

株式会社エー・アンド・ユー:建築と都市 2018 年 4 月別冊 PASSIVETOWN, 2018

13) S. Nishizawa, M. Miyata, Y. Akamine, T. Takao: Development of Calculation Tool of Seasonal Shading Correction Factor for Revised Energy Efficiency Standard, AIJ Journal of Technology and Design, Vol.21, No.49, pp.1111-1116, 2015. 10

西澤繁毅, 宮田征門, 赤嶺嘉彦, 澤地孝男: 改正建築省エネルギー基 準に対応した日よけ効果係数算出ツールの開発, 日本建築学会技術報 告集，第 21 巻，第 49 号，pp. 1111-1116，2015. 10

14) K. Tatematsu, H. Ikeda, M. Takakura, H. Suzuki, A. Fukushima: Research on Thermal Environment of Highly Insulated Houses in Hokkaido Part 1 Measurement of Temperature and Humidity in Summer and Intermediate Season, Summaries of Technical Papers of Annual Meeting, Architectural Institute of Japan, D- II , pp. 397-398, 2010.7

立松宏一，池田裕雅，高倉政寛，鈴木大隆，福島明：北海道における 高断熱住宅の温熱環境調査 その 1 夏期・中間期の温湿度実測結果, 日 本建築学会大会学術講演梗概集, D- II , pp. 397-398, 2010.7

15) Institute for Building Environment and Energy Conservation: Explanation of Energy Consumption Calculation Method in Standard of Judgment of Housing Business 0wners, 2009 財団法人建築環境・省エネルギー機構：住宅事業建築主の判断の基準 におけるエネルギー消費量計算方法の解説， 2009 


\title{
INFLUENCE OF “A THICK WALL” ASSUMING THE EXTERNAL INSULATION METHOD
} ON SOLAR HEAT GAIN QUANTITY AND ANNUAL HEAT LOAD

\author{
Keiichiro TANIGUCHI ${ }^{* 1}$ \\ ${ }^{* 1}$ Project Assist. Prof., Graduate School of Eng., The Univ. of Tokyo, M.Eng.
}

This study focuses on the renovation of apartment houses using the external insulation method which the number of cases is expected to increase in the future, and we conducted a systematic heat load simulation changing the window orientation, the window size (window-to-wall ratio), the window proportion, the type of glass, the thickness of the insulation, to clarify the annual heat load / the heat balance characteristics of each area and the factors that influence it. In addition, we prepared a basic data on the influence of the solar heat gain quantity and the annual heat load due to a difference of the location of window frame in "a thick wall" with thick insulation. Ultimately, the study deduced the following points.

1) In Tokyo, it is necessary to consider a reduction of both the cooling load and the heating load depending on the type of glass used. In the case which the type of glass is a double low-e glass insulating type, the annual heat load can be reduced by decreasing the window-to-wall ratio with the main window direction set to the south.

2) In Sapporo, it is important to consider mainly a reduction of the heating load. However, if the window-to-wall ratio is made too large, the cooling load will increase and the annual heat load will also increase due to the increase in the solar heat gain quantity in summer, so it is necessary to consider the appropriate window size.

3) In Kagoshima, it is important to consider mainly a reduction of the cooling load, and when the window-to-wall ratio is reduced, the annual heat load can be reduced. In addition, as for the glass type, a double low-e heat reflecting type with a low solar heat gain coefficient resulted in the smallest the annual heat load.

4) When a heat load simulation is conducted considering a solar radiation shading effect by "a thick wall", even when the thickness of insulation is $50 \mathrm{~mm}$, the solar heat gain quantity is reduced by $25 \%$ which affects the cooling load and the heating load because of a difference of the location of window frame. Especially in Sapporo where the coldness in winter is severe and it is assumed that the external insulation method using thicker insulation $(200 \mathrm{~mm}$ in this study) is expected to be adopted, both the heating load and the annual heat load increase due to the solar radiation shading effect of the wall thickness.

From this study, it is suggested that it's necessary to simulate shading devices in all openings and reproduce the influence of the solar radiation shading by the wall thickness. In the future, since the annual heat load is greatly affected by the insulation level of external wall or the internal heat generation quantity, we will add further verification, and we plan to develop a method to correctly predict the load reduction effect by the external insulation method. 